\title{
An ancient, yet current, experience of deficient architecture: the case of Doge
}

\author{
A. Pérez Negrete, L. Punzi \\ Italian Society of Rheumatology (SIR) and Institute for the History of Rheumatology (ISR), Venice, Italy
}

$\mathrm{D}^{2}$ ear Editor, architecture has not yet devoted the necessary attention to rheumatic diseases. Unfortunately, those who suffer from them, namely around a quarter of the world population, find the surrounding world full of all kinds of obstacles that make their lives more difficult (1). This circumstance causes serious disruption to the three pillars of physical, mental, and social well-being which, according to the World Health Organization (WHO), represent the essential foundations of the health of all individuals. Hence, these people are rejected and discriminated in the context in which they have previously lived their daily lives, thus experiencing in many cases feelings of failure and social isolation (2).

Such frustration is not exclusive to our era. Maybe this feeling is very similar to that experienced by Doge Andrea Gritti (14551538) (3) when, as his gout was worsening, was forced to modify several habits of both his public and private life. In fact, the leaders of the Serenissima had to usually deal with a large number of official duties at a very advanced age, especially for their times. For example, Doges Cristoforo Moro (1390-1471) and Marcantonio Barbarigo (1413-1486) were elected when they were 72. Similarly, Pietro Lando (1462-1545) was elected at the age of 76 and Leonardo Donà (1536-1612) at 70. If one scrolls down the list of Doges, it is evident that Gritti is one of the 'youngest' of the Modern Age, since he was elected at the age of 68 . For these people political life was full of activities: formal hearings with ambassadors and citizens, processions (around twenty every year) several local celebrations, and even fighting in wars as in the case of Francesco Morosini (1619-1694). In practice, their roles required a robust health.

As to Andrea Gritti and his disease, he was very well-known for overeating. Nicolò Barbarigo stated that «at the table he did not go unnoticed by the crowd often for the poor quality of the food he ate, and even when he was old, he would devour garlic, onions and other such things after dinner, which he avidly enjoyed» (4). These indulgences, in particular, a feast of spit-roasted eels or bean soup, are believed to have caused his death on 28 December 1538. Overeating was likely to be one of the causes of his gout, which caused severe deformities in his feet (5).

Gritti endured the disease until 25 March 1530, the date on which Marin Sanudo revealed an accidental fall of the Doge. It is no coincidence that a month later, on April 24th, he refused to enter the balcony, the place reserved for the ducal office (also called 'bigonzo'), in St. Mark's Basilica since he suffered from «leg aches». This was one of the first occasions in which the disease started to interfere with the Doge's ordinary life. From that day on, Gritti's limited mobility caused a disruption to the choir within the St Mark's Basilica. Jacopo Sansovino coordinated an operation to place the Doge to the right of the choir, fac-
Corresponding author: Alberto Pérez Negrete, Institute for the History of Rheumatology (ISR), Campo SS Giovanni e Paolo, Castello 6777, 30122 Venice, Italy. E-mail: albertopereznegrete@gmail.com 
ing the main altar, in the place usually occupied by the 'Primicerio', the head of the ancient Venetian church $(6,7)$. The main purpose of the intervention was for the Doge to avoid the narrow space and the stairs to reach the balcony. This had several consequences in the ceremonies, already studied by Andrew Hopkins (8). Despite this different position, which was more suitable for the Doge disability, the disease progressed, causing Gritti to be absent from the 'Collegio' (the heart of the government) on a number of occasions, as he «could not feel his legs». He even asked for permission to leave the Doge's Palace in order to go to his residence on the island of Murano. His reduced mobility as well as his excessive consumption of food made the Doge gain weight. Hence, on May $8^{\text {th }}, 1532$, he again did not walk up to the balcony, since «he was fat», and preferred to remain in the choir. Similarly, a month later, the Doge had to travel by boat to San Vito's church, where he was required to attend mass. However, he was «not able to walk» (9).

In our opinion, this shows how rheumatic diseases, at all times, affected the lives of ordinary and illustrious and influential people. Gritti was just one of the many Doges affected by these diseases. Yet, despite the suffering and reduced functions of the Doge, up to now there has been no evidence of any planned changes to the accessibility of the basilica. Therefore, perhaps the Schools of
Architecture should bear these facts in mind, since the lack of attention for these aspects contributes to the exclusion of people who suffer from rheumatic diseases, thus amplifying their disabilities.

\section{REFERENCES}

1. Punzi L, Chia M, Cipolletta S, et al. The role of architectural design for rheumatic patients' wellbeing: the point of view of Environmental Psychology. Reumatismo. 2020; 72: 60-6.

2. Ministero della Salute. Piano d'azione per la Salute mentale 2013-2020. Available from: http://www.salute.gov.it/imgs/C_17_pubblicazioni_2448_allegato.pdf

3. Benzoni G, Gritti, Andrea. Dizionario Biografico degli Italiani. Roma: Istituto della Enciclopedia Italiana. 2002; vol. 59: ad vocem.

4. Barbarigo N. Andreae Gritti principis Venetiarum vita Nicolao Barbadico auctore Alexandro Albritio procuratoris divi Marci dignitatem ineunte primum edita. Venezia: Carlo Palese. 1792; 53.

5. Da Mosto A. I Dogi di Venezia. Venezia: Ferdinando Ongania editore. 1939; 158-163: 162.

6. Boucher B. The sculpture of Jacopo Sansovino. New Haven-London: Yale University Press. 1991; I, 56; II, 329-330, cat 22.

7. Morresi M. Jacopo Sansovino. Milano: Electa. 2000; 167-169.

8. Hopkins A. Symbol of Venice: the Doge in ritual. In: Cohn S, Fantoni M, et al. Late medieval and early modern ritual: studies in Italian urban culture. Turnhout: Brepols. 2013; 227-39.

9. Hopkins A. Architecture and Infirmitas: Doge Andrea Gritti and the Chancel of San Marco. J Soc Architect Histor. 1998; 57: 182-97. 